\title{
Diagnosis dan Penatalaksanaan Tragus Asesorius dan Stenosis Liang Telinga pada Hemifasial Mikrosomia
}

\author{
Al Hafiz, Jacky Munilson, Effy huriyati, Yan Edward, Sylvia Rachman, Gunawan Yudhistira
}

\section{Abstrak}

Hemifasial mikrosomia (HFM) adalah diagnosis paling sering pada lesi wajah asimmetris dan merupakan kelainan kongenital wajah terbanyak kedua. HFM merupakan malformasi kongenital dimana terdapat defisiensi jaringan lunak dan tulang pada satu sisi wajah dan gangguan perkembangan telinga, terutama telinga luar. Diagnosis ditegakkan berdasarkan pada anamnesis, pemeriksaan fisik, dan pemeriksaan radiologis. HFM memiliki manifestasi klinis yang beragam, dan dipertimbangkan mendapatkan penatalaksanaan komprehensif yang melibatkan rekontruksi medik luas.

Sebuah kasus hemifasial mikrosomia dengan tragus asesorius dan stenosis liang telinga kanan dilaporkan pada perempuan berusia 13 tahun dan telah dilakukan rekonstruksi tragus dan kanaloplasti.

Kata kunci: hemifasial mikrosomia, lesi wajah asimmetris, rekontruksi tragus, kanaloplasti.

\begin{abstract}
Hemifacial microsomia (HFM) is the most frequent diagnosis in asymmetry facial lesions and the top second facial congenital lesion. HFM is a congenital malformation in which there is a deficiency of soft tissue and bone on one side of the face and malformation of the ear, especially outer ear. The diagnosis is based on history, physical examination, and radiological finding. HFM had various clinical manifestation and considered to comprehensive management involving extensive medical reconstruction. A hemifacial microsomia case with right tragal assesoria and ear canal stenosis has been reported in girl aged 13 years old and have performed tragus reconstruction and canaloplasty.
\end{abstract}

Keywords: hemifacial microsomia, asymmetrical facial lession, tragus reconstruction, canaloplasty

Affiliasi penulis : Gunawan Yudhistira

Korespondensi : 6unawanyudhistira@gmail.com Telp: 081372592742

\section{PENDAHULUAN}

Hemifasial mikrosomia (HFM) merupakan malformasi kongenital dimana terdapat defisiensi sejumlah jaringan lunak dan tulang pada satu sisi wajah yang ditandai dengan disgenesis wajah mencakup berbagai derajat hipoplasia/ aplasia dari komponen kerangka tulang pembentuk wajah. ${ }^{1,2}$ Lesi ini merupakan bagian dari sindrom arkus brankial pertama dan kedua mencakup gangguan perkembangan sendi temporomandibula, ramus mandibula, otot-otot mastikator, telinga, dan terkadang defek otot dan saraf wajah.,

Pada tahun 1963, istilah displasia OculoAuriculo-Vertebral (OAV) diperkenalkan sebagai terminologi inklusif untuk kelainan seperti HFM dan anomali lain di wajah. Displasia OAV terdiri dari kelainan presentasi klinis yang sangat beragam, melibatkan jaringan lunak wajah, tengkorak, orbita, maksila, mandibular, telinga, dan sistem saraf (khususnya saraf kranial dan mata). HFM merupakan subtipe dari displasia OAV yang ditandai dengan hipoplasia mandibular dan keterlibatan gangguan telinga. Pada rentang cakupan displasia OAV, sindrom Goldenhar sering kali dianggap sebagai varian HFM dan bermanifestasi sebagai epibulbar dermoid, auricular appendages dan sinus preaurikula, hipoplasia mandibula dan anomali vertebra. Sindrom Goldenhar terjadi pada $10 \%$ dari seluruh kelainan OAV. Sindrom ini dapat disertai atau tanpa mikrotia. ${ }^{1,5}$

HFM adalah diagnosis paling sering pada lesi wajah asimmetris dan kelainan kongenital wajah terbanyak kedua setelah celah pada bibir dan palatum dengan laporan insiden antara 1:5000 dan 1:5600 angka kelahiran. Lesi ini lebih banyak mengenai pria dibandingkan wanita (3:2). Meskipun "Hemifasial" mengacu pada satu sisi wajah, kondisi defek bilateral terdapat pada $31 \%$ kasus, dengan salah satu sisi wajah memiliki kondisi yang lebih berat. Pada $48 \%$ kasus, lesi ini merupakan bagian dari sindrom Goldenhar. ${ }^{3,6}$

Penatalaksanaan pasien dengan HFM sangat kompleks dan dalam jangka waktu lama, serta membutuhkan operasi gabungan dengan beberapa spesialis termasuk ahli bedah dan gigi. ${ }^{3,6}$

Hipoplasia dapat bermanifestasi pada berbagai struktur yang dibentuk oleh arkus brankial pertama dan kedua, mengingat luasnya cakupan deformitas yang ada pada kelainan ini. Beberapa teori telah diajukan sebagai usaha untuk memahami mekanisme etiopatogenesis pada HFM. Teori yang 
paling banyak diterima adalah teori teratogenik pada kerusakan vaskular, dengan pembentukan hematoma dan pendarahan pada saat perkembangan arkus brankial pertama dan kedua dan kemudian menyebabkan gangguan perkembangan.,

Pada penelitian tentang evolusi arteri kranium pada embrio manusia, menjelaskan pembentukan pembuluh darah wajah ditentukan oleh beberapa pintasan dan anastomosis termasuk arkus aorta primitif. Arkus aorta pertama dengan cepat menghilang tetapi tidak menghilang sebelum arteri mandibula mensuplai daerah anterior maksila. Seiring dengan regresi arkus pertama, arteri stapedius terbentuk dari arkus kedua pada hari ke-33 usia kehamilan. Arteri ini mensuplai struktur wajah sampai dengan perkembangan arteri karotis eksterna mencapai daerah wajah pada kehamilan hari ke-45.,9

Defek dari arteri stapedius akan menyebabkan pendarahan, dan cedera pada perkembangan arkus brankial pertama dan kedua. Cakupan patologi sangat beragam tergantung volume pendarahan, mulai dari hanya keterlibatan telinga luar dan tulang pendengaran sampai pada defek lebih luas yang melibatkan kompleks zigomatika dan keseluruhan mandibula pada sisi wajah yang terkena. ${ }^{7,8}$

Kelainan ini juga dikaitkan dengan ibu pengidap diabetes, ibu yang mengkonsumsi thalidomide dan ibu yang terpapar obat teratogenik seperti asam retinoat. ${ }^{3}$ Saat ini masih belum ada bukti klinis bahwa kelainan ini berkaitan dengan transmisi genetika. $^{2,7}$ Pada kasus yang jarang peningkatan insiden pada garis keturunan keluarga telah dilaporkan, dimana terdapat lesi yang diturunkan secara genetis. Pada kedua orang tua tanpa kelainan dengan satu anak dengan HFM, kemungkinan anak berikutnya memiliki kondisi yang sama kurang dari $1 \%$. Orang tua dengan HFM memiliki kemungkinan $3 \%$ menurunkan pada anak-anaknya. Penyebab kelainan ini diperkirakan multi faktorial dan sangat bervariasi manifestasi klinisnya. ${ }^{1,3}$

Kelainan jaringan lunak wajah dapat sangat bervariasi secara klinis. Sekurang-kurangnya keterlibatan jaringan lunak pada lesi ini adalah keberadaan sisa kartilago ektopik yang dihubungkan dengan skin appendages, sering kali disalah artikan sebagai skin tag. Kelainan ini sering ditemukan pada daerah pipi preaurikula. Manifestasi klinis minor lainnya termasuk sinus yang muncul pada telinga luar. $^{3,6}$

Kelainan jaringan lunak termasuk makrostomia, dengan hipoplasia dan kelainan seluruh jaringan lunak pipi. ${ }^{3}$ Lesi ini dapat disertai hipoplasia atau agenesis duktus kelenjar parotis atau bahkan keseluruhan kelenjar parotis. Fistula kelenjar ludah dapat terjadi. ${ }^{3,6}$

Hipoplasia otot pipi dan wajah sering ditemui. Hipoplasia muskular dapat mempengaruhi derivat otot arkus brankial pertama, otot-otot yang dipersarafi saraf kranial V, yaitu; otot masseter, temporalis, tensor veli palatini, pterigoid dan derivat otot arkus brankial kedua, otot-otot yang diinervasi saraf kranial VII, yaitu; otot-otot wajah, levator veli palatini, uvula serta dapat menyebabkan hipoplasia lidah yang signifikan.,7

Pada HFM, abnormalitas mandibula paling sering ditemui pada kerangka tulang kraniofasial, tulang lain juga ikut terlibat seperti maksila, temporal dan zigoma. Kelainan pada mandibula sangat bervariasi mulai dari mandibula dengan defek ringan sampai malformasi berat tanpa angulus atau ramus mandibula. Hipoplasia kondilus dan ramus dapat menyebabkan deviasi posisi dagu pada sisi yang terkena dan pengurangan ukuran panjang wajah sisi posterior menyebabkan sudut pada angulus mandibula menghilang. Hipoplasia kondilus ditemukan sampai dengan $90 \%$ dari seluruh kasus. ${ }^{1,3}$

Kegagalan perkembangan komplit dari zigoma dapat terjadi. Keterlibatan maksila dan mandibula memiliki implikasi pada oklusi gigi dan estetika wajah. Sebagai tambahan, lesi ini dapat melibatkan berbagai derajat kelainan gigi. Hipodontia ditemukan pada $27 \%$ kasus HFM dan sangat erat berhubungan dengan derajat kelainan mandibula. ${ }^{1,8}$

Kubah kranium dapat terjadi kelainan, meskipun anomali pada komponen ini jarang. Tulang frontalis dapat berkembang miring dan terdorong ke belakang, membuat tampilan plangiocephaly, meskipun tanpa bukti keberadaan synostosis. Keterlibatan tulang frontalis dan orbita ini oleh beberapa ahli mendiskripsikan sebagai kraniofasial mikrosomia. Perkembangan tulang orbita yang normal atau terjadi hipoplasia akan sangat berpengaruh terhadap perkembangan mata. Hipoplasia dapat terjadi pada tulang temporal dan dapat melibatkan tulang hipoplasia mastoid serta kegagalan pembentukan aerasi mastoid. 1,3,6

Lokasi anomali ekstra kranial yang tersering adalah tulang servikal, dimana terjadi pada $30 \%$ kasus. Lesi ini sangat bervariasi mulai dari oksipitalisasi atlas, fusi vertebra atau spina bifida. Pada tulang iga dapat ditemui kelainan seperti agenesis iga, duplikasi iga, fusi iga yang berdekatan atau jumlah iga yang berlebih. ${ }^{1,7}$

Kelainan telinga dapat mengenai telinga luar, tengah atau dalam. Pada studi Rollnick dkk. ${ }^{10}$ dari 294 kasus, didapat mikrotia unilateral sebanyak 193 kasus, bilateral pada 98 kasus dan pasien mikrotia yang simetris 34 dari 98 kasus bilateral. Telinga luar bisa saja pada posisi normal dengan orientasi normal atau kelainan lokasi lebih ke posterior atau ke anteroinferior. Stenosis liang telinga luar terjadi pada $30-40 \%$ kasus. Atresia secara umum ditemukan pada kasus yang lebih berat. Hipoplasia telinga tengah ditemui pada sekitar $70 \%$ kasus dan atresia telinga tengah sekitar $20 \%$ kasus. Osikel telinga tengah mengalami malformasi dan fusi pada sekitar $80 \%$ pasien dengan HFM. Tuba eustachius bisa saja tidak terbentuk. Secara fungsional, pada umumnya seluruh pasien memiliki 
komponen tuli. Tuli konduktif ditemui pada $86 \%$ pasien dan tuli sensorineural $10-15 \%$ dari seluruh pasien. ${ }^{1,10}$

Kelainan pada mata sangat beragam mulai dari kelainan asimetris ringan yaitu mikrophtalmia sampai dengan anopthalmia, blepharoptosis atau peyempitan fissura palpebra terdapat pada $10 \%$ kasus. ${ }^{1}$ Sindrom Goldenhar, yang pertama kali dikemukakan pada tahun 1950-an, terdiri dari epibulbar dermoid yang muncul sebagai gambaran tempelan kulit yang meluas dari konjungtiva sampai kornea mata. Epibulbar dermoid lebih sering muncul unilateral dibanding bilateral. Sindrom Goldenhar umumnya mencakup hipoplasia mandibula, anomali vertebra dan lesi kongenital preaurikuler atau pit, dan sejak lama telah dikenal sebagai subgrup dari HFM. Koloboma kelopak mata atas telah dilaporkan pada $20 \%$ kasus. Kelainan pergerakan bola mata didapat $25 \%$ dari kasus, termasuk esotropia, eksotropia dan sindrom Duane. ${ }^{1,3,6}$

Abnormalitas serebral, meskipun jarang, dapat ditemui mencakup hipoplasia serebri dan corpus callosum, hidrosefalus tipe obstruksi. Batang otak dapat terlibat sekunder dari anomali servikal vertebra, menyebabkan gangguan seperti penekanan batang otak. ${ }^{7,10}$

Anomali kranial paling umum ditemui adalah berbagai derajat parese fasial, yang disebabkan (sendiri atau kombinasi): ketiadaan saraf dan nukleus fasialis intrakranial pada batang otak, kelainan jalur saraf pada tulang temporal atau agenesis otot-otot fasialis. Ketiadaan fungsi cabang marjinal mandibula saraf fasialis ditemui pada $25 \%$ pasien, dengan kelemahan komponen lain, seperti cabang bukal dan zigoma, dengan angka kejadian kecil. ${ }^{3,7}$

Sistem klasifikasi pertama untuk pasien HFM dan displasia OAV dikemukakan oleh Pruzansky pada 1969, dan menjadi pedoman untuk sistem klasifikasi berikutnya. Pruzansky menggambarkan tiga tipe hipoplasia mandibula: ${ }^{1}$

1. Tipe I; bentuk dan morfologi mandibula secara umum normal, meskipun mandibula memiliki ukuran lebih kecil dibandingkan sisi kontralateral yang "normal".

2. Tipe II; kondilus, ramus, dan prosesus sigmoid, meskipun masih ada tapi secara umum terganggu dan ukuran serta bentuk mandibula menyusut dari ukuran normal yang ideal.

3. Tipe III; ketiadaan ramus dan fossa glenoid, terutama tanpa perkembangan posterior mandibula sampai dengan agenesis folikel gigi.

Pruzanky seperti dikutip oleh Havlik, menghubungkan derajat perkembangan mandibula dengan anomali telinga pada 90 pasien, didasarkan klasifikasi telinga yang dipublikasikan oleh Meurman. ${ }^{1}$

Pada tahun 1988, Kaban dan Mulliken seperti dikutip oleh Havlik, mengemukakan modifikasi dari sistem klasifikasi Pruzansky tipe II menjadi grup tipe Ila dan tipe Ilb berdasarkan lokasi dan posisi temporomandibular joint (TMJ). Pada sistem klasifikasi ini (Gambar.1), mandibula tipe Ila memiliki kelainan morfologi, tetapi masih memiliki fungsi dan posisi TMJ yang baik untuk menunjang pembukaan simetris dari mandibula. Sebaliknya, pada pasien tipe Ilb, terdapat malposisi TMJ lebih ke arah inferior, medial dan anterior. ${ }^{1,7}$

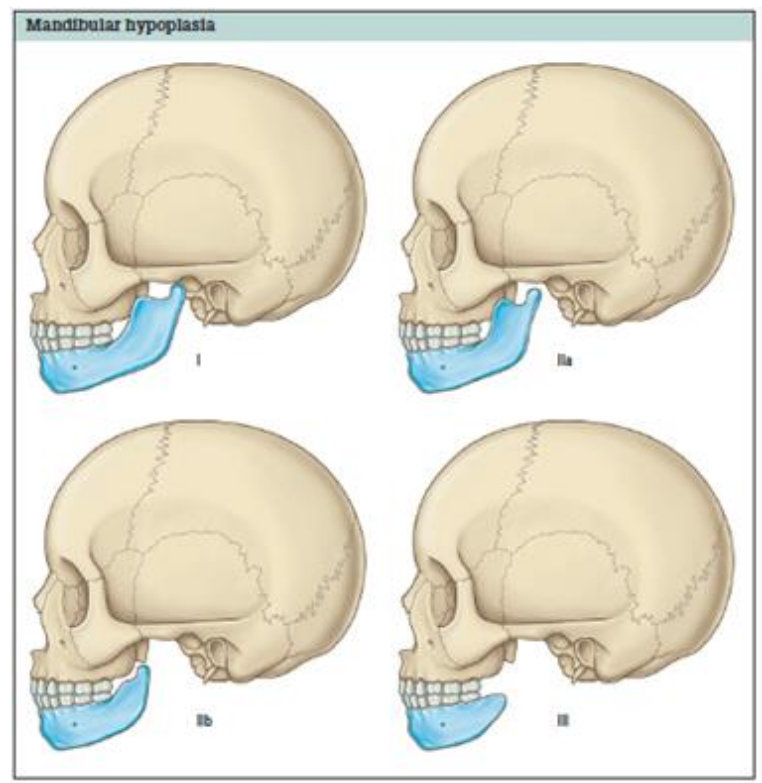

Gambar 1. Sistem Klasifikasi modifikasi Kaban dan Mulliken dari klasifikasi hipoplasia mandibular Pruzansky. ${ }^{1}$

Sistem klasifikasi Pruzansky dan sistem Kaban dan Mulliken yang merupakan modifikasinya memiliki fokus pada mandibula dan TMJ. Beberapa sistem klasifikasi lain telah dipublikasikan dengan tujuan memperoleh gambaran lebih komprehensif terhadap anomali yang ada pada kelainan OAV. Sistem OMENS dikemukakan pada tahun 1991 dan sistem OMEN-plus pada 1995. Kedua sistem ini mencoba menyediakan kerangka untuk sistem klasifikasi yang lebih komprehensif untuk berbagai anomali yang terdapat pada kelainan OAV. Huruf $O$ untuk menggambarkan morfologi dari orbita dan bervariasi mulai dari ukuran dan posisi normal $\left(\mathrm{O}_{0}\right)$ sampai dengan posisi dan ukuran yang abnormal $\left(\mathrm{O}_{3}\right)$. Huruf $\mathrm{M}$ untuk derajat mandibula mulai dari normal $\left(\mathrm{M}_{0}\right)$ sampai dengan aplasia komplit dari ramus, fossa glenoid dan TMJ $\left(\mathrm{M}_{3}\right)$ dan derajat ini berdasarkan sistem anomali mandibula Pruzansky. Huruf $\mathrm{E}$ menggambarkan abnormalitas telinga dan bervariasi mulai dari normal $\left(E_{0}\right)$ sampai dengan malposisi lobulus pada agenesis aurikel. Huruf $\mathrm{N}$ untuk menilai tingkat keterlibatan saraf fasial $\left(\mathrm{N}_{0}\right.$ sampai dengan $\mathrm{N}_{3}$ ) dan huruf $\mathrm{S}$ untuk menilai derajat defisiensi jaringan lunak. Sistem OMENS-plus menambahkan evaluasi kelainan ekstra-kraniofasial. Sistem klasifikasi ini mudah untuk digunakan dan sangat jelas serta bermanfaat untuk sistem rekam medik institusi dalam menatalaksana pasien dalam jumlah besar. ${ }^{1,3,11}$

Meskipun memiliki manifestasi klinis yang beragam, pasien dengan HFM harus mendapatkan penatalaksanaan komprehensif yang melibatkan rekonstruksi medik luas meliputi jaringan lunak dan 
keras untuk maksila dan mandibula, telinga dan orbita. Beberapa kasus membutuhkan penatalaksanaan orthodontis, alat bantu dengar dan perbaikan bahasa untuk memperbaiki fungsi dan tampilan. Pendekatan psikologis menjadi penting untuk dilakukan pada anak dengan HFM selama masa pertumbuhan., ${ }^{3,12}$

Beberapa laporan pendekatan pembedahan wajah asimetris pada HFM telah dilaporkan. Salah satunya berpendapat bahwa terapi definitif tidak akan tercapai sampai pertumbuhan wajah selesai, tetapi saat ini lebih banyak peneliti berpendapat bahwa diagnosis dan penatalaksanaan dini HFM akan memberikan banyak manfaat. Perbaikan abnormalitas mandibula saat masa kanak-kanak memberikan manfaat pertumbuhan rangka midfasial yang simetris kemudian dan potensi untuk pertumbuhan struktur jaringan sekitarnya, meminimalisir deformitas sekunder dan meningkatkan fungsi serta penampilan. $^{1,12}$

Penelitian retrospektif terhadap pertumbuhan kondilus/ ramus yang telah dikoreksi pada HFM, menyimpulkan bahwa graft kosto-kondral sering mengalami pertumbuhan dalam ukuran dan panjang. ${ }^{12}$ Pertumbuhan ini biasanya terjadi setelah 2 tahun pemasangan graft dengan pertumbuhan yang lambat dan tidak sama dengan jaringan sekitar.,12

Pada penatalaksanaan HFM secara umum terdapat 2 pendekatan; intervensi bedah pada masa awal (selama masa pertumbuhan) dan lanjut (setelah masa pertumbuhan). Pendekatan masa awal, prosedur bedah konvensional atau tindakan distraksi dapat diterapkan. Pada prosedur konvensional, ramus mandibula hipoplasia digantikan dengan graft autologus kosto-kondral. Graft ini disukai karena masih memiliki potensi tumbuh untuk tujuan mengejar pertumbuhan sisi wajah tanpa lesi. Posisi dagu harus dikembalikan ke tengah selama prosedur ini. Pada anak, kebanyakan operasi tunggal sudah cukup mengkoreksi wajah asimetris. Pada beberapa institusi memilih tindakan distraksi sebagai pendekatan masa awal, karena kelemahan prosedur konvensional yaitu masalah graft kosto-kondral overgrowth. Pendekatan masa lanjut terdiri dari osteotomi klasik (pembedahan maksila, dengan pemotongan maksila dikombinasikan dengan pemanjangan ramus mandibula) dan bimaxillary distraction osteogenesis (metode OrtizMonasterio). Tehnik osteogenesis distraksi telah banyak dipakai di dunia dan diterapkan untuk manajemen deformitas dan defek tulang berat pada kompleks kraniofasial. Prosedur ini memungkinkan pertumbuhan tulang baru yang memiliki karekteristik sama dengan tulang disekitarnya. Kekuatan traksi pada tulang juga memberikan tegangan pada jaringan lunak, memicu rangkaian perubahan adaptif yang disebut histogenesis distraksi. Proses ini menyebabkan terjadi pertumbuhan baru jaringan lunak mengikuti pertumbuhan tulang baru. ${ }^{3,6}$

Pasien dengan HFM biasanya mengalami tuli konduktif sekitar $50 \%$ yang dihubungkan dengan kelainan telinga tengah. Pembedahan rekontruksi telinga adalah salah satu tantangan yang dihadapi ahli bedah plastik karena kompleksitas struktur telinga. ${ }^{6,12}$

Penentuan waktu pembedahan rekontruksi telinga sangat penting, dianjurkan pada usia 6-7 tahun. Pada usia ini pemeriksaan audiometri telah dapat dilakukan dengan akurat, pneumatisasi tulang temporal telah optimal dan anak lebih kooperatif untuk perawatan pasca operasi. Pada pasien mikrotia yang membutuhkan operasi rekontruksi luas direkomendasikan rekontruksi daun telinga terlebih dahulu untuk reposisi sebelum dilakukan kanaloplasti. ${ }^{3,12}$

Pasien dengan stenosis liang telinga berisiko untuk kolesteatom dan dianjurkan operasi. Predisposisi perkembangan kolesteatom pada diameter liang telinga $2 \mathrm{~mm}$ atau kurang dan dimulai pada masa dewasa muda. Pendekatan operasi stenosis liang telinga melalui pendekatan anterior dan mastoid. Pendekatan anterior memberikan keuntungan lebih karena akses kavitas mastoid lebih luas sehingga dapat mencegah terjadinya akumulasi debris dan infeksi pasca operasi. ${ }^{3,12}$ Prinsip penentuan waktu yang tepat untuk rekontruksi deformitas fasial tergantung usia, berat penyakit, dan sisi psikologis. ${ }^{12}$

\section{LAPORAN KASUS}

Seorang pasien anak perempuan berusia 13 tahun datang ke poliklinik THT-KL RS. M. Djamil Padang pada 8 Juli 2014 dengan keluhan utama benjolan pada daun telinga kanan, wajah sisi kanan mencong dan sudut bibir kanan turun sejak lahir. Benjolan pada daun telinga kanan bertambah besar sesuai pertumbuhan daun telinga kanan seiring pertambahan umur dan tidak ada nyeri tekan. Benjolan yang sewarna dengan kulit di mata kanan sejak lahir dan tidak bertambah besar. Liang telinga kanan sempit sejak lahir. Pendengaran telinga kanan berkurang sejak 4 tahun yang lalu, makin lama makin berat. Riwayat telinga berair sebelumnya tidak ada dan tidak ada riwayat anggota keluarga lain yang memiliki penyakit yang sama seperti ini. Riwayat trauma dan konsumsi obat-obatan tidak ada selama kehamilan. Riwayat ibu pasien menderita diabetes tidak ada.

Pada pemeriksaan fisik, kondisi umum baik dan tanda vital dalam batas normal. Pemeriksaan khusus THT-KL, pada regio preaurikular kanan terdapat benjolan sewarna kulit berukuran $3 \times 2 \times 2 \mathrm{~cm}$ di tragus, nyeri tekan tidak ada dan terdapat pit. Pemeriksaan liang telinga kanan sempit dan membran timpani sukar dinilai. Regio retroaurikuler tenang, massa tidak ada. Pemeriksaan regio preaurikuler dan retroaurikuler kiri dalam batas normal, liang telinga kiri lapang, membran timpani utuh dan ada reflek cahaya. Pemeriksaan rongga mulut dan tenggorok, didapatkan tidak ada trismus dan maloklusi, arkus faring simetris, uvula ditengah, tonsil kanan dan kiri berukuran T3 
dengan kripti melebar, dan dinding faring posterior tenang. Pada rinoskopi posterior didapatkan hipertrofi adenoid dan muara tuba eustachius terbuka. Pemeriksaan hidung dalam batas normal. Pada regio maksilofasial kanan, terdapat hipoplasia pada tulang maksila kanan, zigomatika kanan, dan submandibula kanan, tidak terdapat krepitasi dan nyeri tekan. Pada regio orbita dekstra, terdapat massa sewarna kulit berukuran $2 \times 1 \times 0,5 \mathrm{~cm}$ dari daerah kantus lateral sampai konjungtiva bulbi (Gambar 2 dan 3). Pada pemeriksaan vertebra servikal, torakal dan lumbal tidak ditemukan kelainan.

Diagnosis kerja pada pasien ini adalah hemifasial mikrosomia dengan tragus asesorius telinga kanan, stenosis liang telinga kanan dan suspek kista dermoid orbita dekstra. Diagnosis diferensial antara lain displasia Oculo-Auriculo-Vertebral (OAV), dan sindrom Goldenhar. Diagnosis tambahan adalah tonsilitis kronis dan hipertrofi adenoid. Pasien kemudian direncanakan untuk pemeriksaan laboratorium darah lengkap, audiometri, ronsen polos toraks, tomografi komputer mastoid dan sinus paranasal 3D (tiga dimensi), konsultasi ke subbagian Neurotologi, Laringofaringologi THT-KL dan ke Bagian Mata RSUP.M.Djamil.
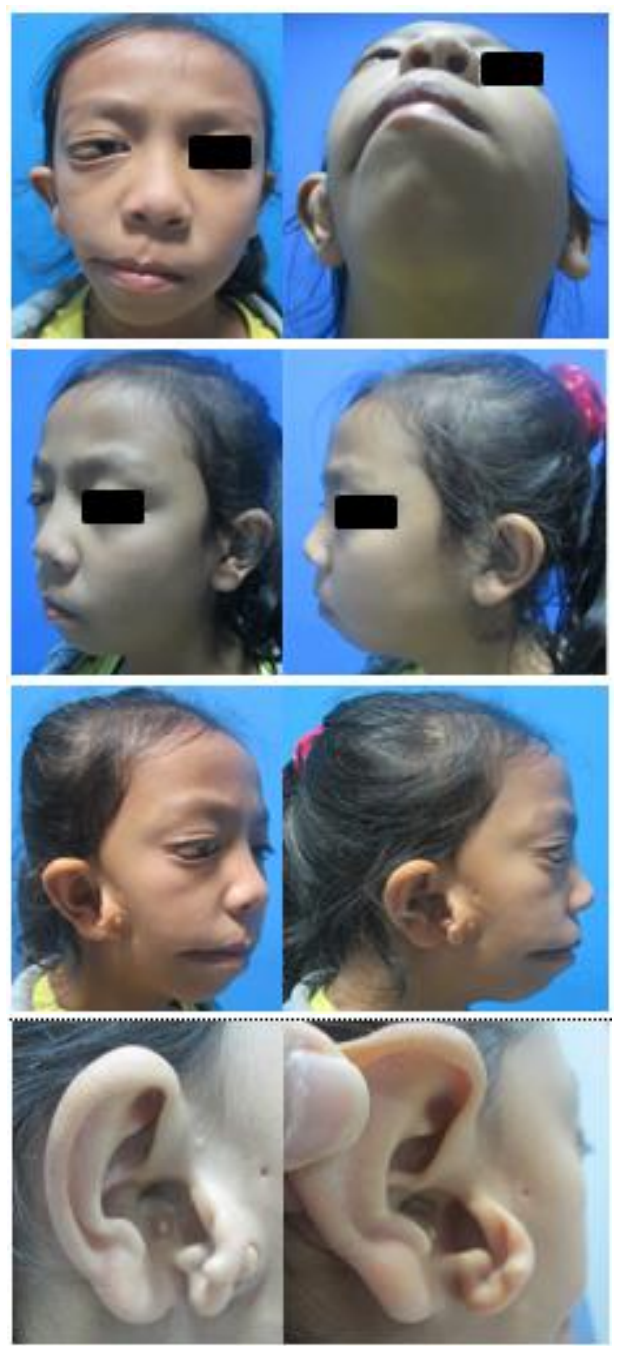

Gambar 2. Foto Pasien.
Pada tanggal 15 Juli 2014, hasil pemeriksaan laboratorium darah, hemoglobin $14,6 \mathrm{~g} / \mathrm{dl}$, hematokrit $42 \%$, leukosit $17.800 / \mathrm{mm} 3$, trombosit $322.000 / \mathrm{mm} 3$, klorida $104 \mathrm{mmol} / \mathrm{L}$, kalium 4,1 mmol/L, natrium 138 $\mathrm{mmol} / \mathrm{L}$, gula darah sewaktu $140 \mathrm{mg} / \mathrm{dl}$, ureum 16 $\mathrm{mg} / \mathrm{dl}$, kreatinin 0,8 mg/dl, PT 11,4 detik, dan APTT 43,4 detik. Hasil pemeriksaan Audiometri, telinga kanan didapatkan jenis tuli konduksi derajat sedang dengan ambang dengar 43,75 dB, telinga kiri normal dengan ambang dengar $12,5 \mathrm{~dB}$. Hasil pemeriksaan ronsen polos toraks, jantung dan paru dalam batas normal.

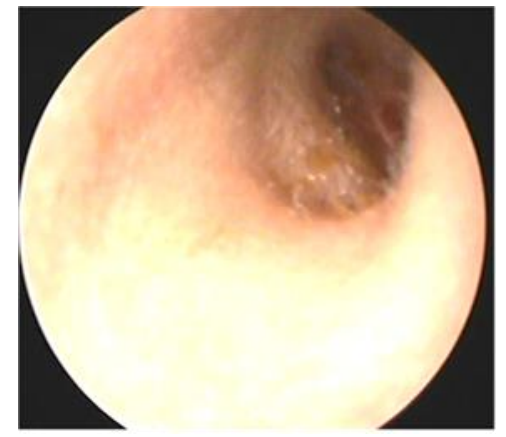

Gambar 3. Foto Liang Telinga Kanan Pasien

Hasil tomografi komputer mastoid didapatkan gambaran deformitas aurikuler dekstra, disgenesis canalis akustikus eksternus dan internus, tulang-tulang pendengaran dan membran timpani telinga kanan dan kiri baik, vestibuli dan koklea baik, pneumatisasi air cell mastoid kanan baik, tidak tampak sklerotik, dan mastoid kiri baik. Kesimpulannya adalah disgenesis (deformitas) aurikuler dekstra, disgenesis akustikus eksternus-internus dekstra, tulang-tulang pendengaran baik (Gambar 4).

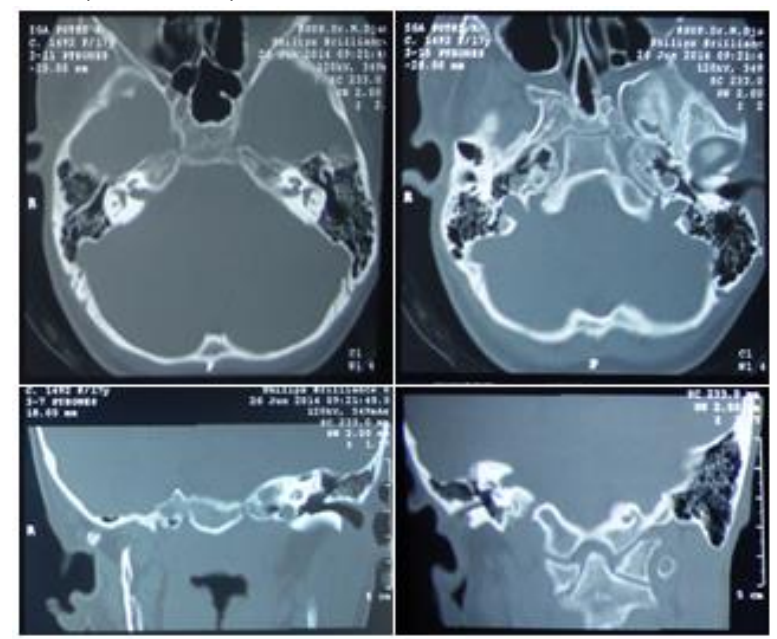

Gambar 4. CT scan Mastoid potongan aksial dan koronal.

Hasil tomografi komputer sinus paranasal 3D, tampak os zigomatikum kanan dan korpus, angulus serta ramus mandibula kanan rudimenter, tidak tampak perselubungan maupun penebalan mukosa pada sinus maksila, ethmoid, dan spenoid dengan sinus frontalis yang tidak berkembang, kompleks osteomeatal dan resesus frontalis terbuka, konka nasalis kanan dan kiri tidak tampak hipertrofi, septum nasi ditengah, rongga nasofaring baik. Kesimpulannya 
adalah tidak tampak gambaran rinosinusitis kronis dan rudimenter dari os zigomatika, korpus, angulus dan ramus mandibula kanan (Gambar 5). Pasien dianjurkan untuk pemeriksaan analisis kromosom tapi keluarga pasien menolak.

Hasil konsultasi pada bagian Mata RSUP. M. Djamil, pasien didiagnosis dengan tumor konjungtiva orbita dekstra suspek kista dermoid, rencana eksisi massa dalam anastesi umum. Hasil konsultasi pada subbagian otologi THT-KL, pasien didiagnosis dengan stenosis liang telinga kanan dan hemifasial mikrosomia, rencana kanaloplasti liang telinga kanan gabung operasi dengan subbagian plastik rekontruksi THT-KL. Hasil konsultasi pada subbagian Neurotologi THT-KL, tidak didapatkan parese saraf fasialis dengan fungsi motorik terbaik $100 \%$ dan tuli konduktif telinga kanan derajat sedang dengan ambang dengar 43,75 $\mathrm{dB}$.

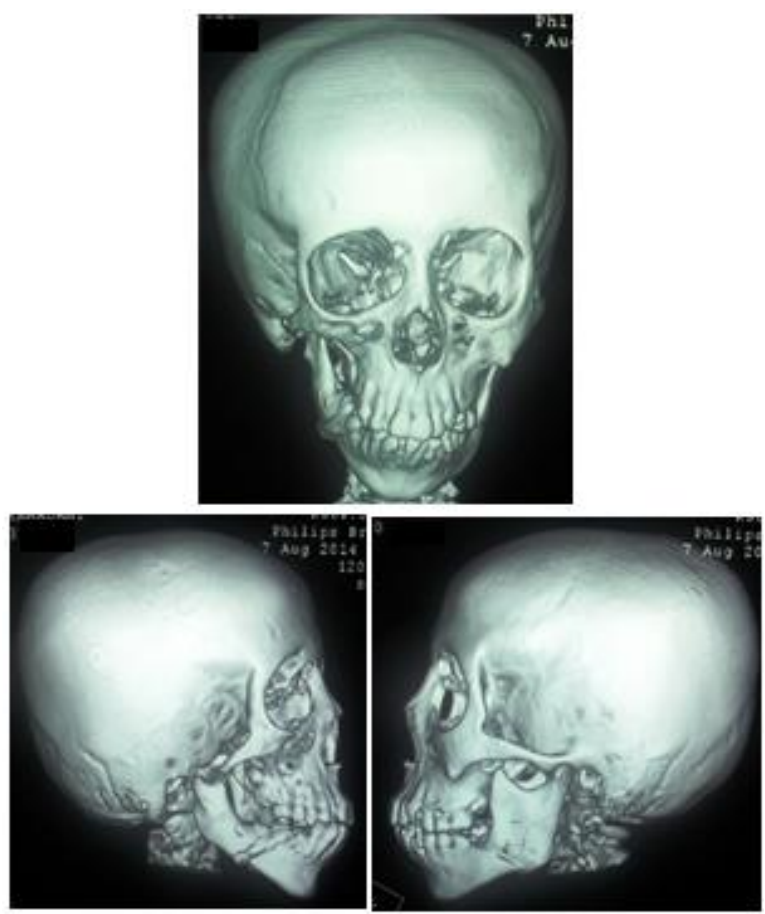

Gambar 5. CT scan sinus paranasal 3D.

Pada tanggal 16 Juli 2014, hasil konsultasi pada subbagian Laringofaringologi THT-KL, pasien didiagnosis dengan tonsilitis kronis dan hipertrofi adenoid serta dipersiapkan dan direncanakan untuk dilakukan tonsiloadenoidektomi dalam anastesi umum.

Pada tanggal 18 Juli 2014 dilakukan tonsiloadenoidektomi oleh subbagian laringofaringologi.

Diagnosis pasien ini adalah hemifasial mikrosomia dengan tragus asesorius, stenosis liang telinga kanan, dan suspek kista dermoid OD. Diagnosis diferensial adalah displasia OAV, dan sindrom Goldenhar. Pasien direncanakan untuk rekontruksi tragus dan kanaloplasti liang telinga kanan dalam anastesi umum.

Pada tanggal 9 september 2014, pasien ini dilakukan kanaloplasti dengan pendekatan retroaurikuler dan rekontruksi tragus telinga kanan. Pertama, pasien tidur telentang dalam anstesi umum dan dilakukan prosedur aseptik-antiseptik. Infiltrasi dengan lidokain 1:200.000 pada sulkus retroaurikuler dan pada liang telinga kanan sesuai proyeksi arah jarum jam pukul 3, 9 dan 12. Insisi $2 \mathrm{~mm}$ dari sulkus retroaurikuler kanan dan dilakukan secara tangensial terhadap liang telinga. Kemudian dilakukan elevasi kulit liang telinga (meatal flap), didapatkan liang telinga sempit dan membran timpani yang kecil. Liang telinga diperlebar dengan pengeboran dan dilakukan meatoplasti. Meatal flap dikembalikan ke posisi semula, liang telinga lebih lapang dan tidak ada bagian tulang liang telinga yang terpapar. Luka insisi dijahit lapis demi lapis. Kemudian, dilakukan tindakan rekontruksi tragus. Pertama lakukan infiltrasi lidokain 1:200.000 pada daerah insisi di tragus asesorius. Insisi pada tragus, kartilago dibebaskan dari perikondrium. Sebagian kulit dan kartilago pada tragus dibuang, lalu sisa kartilago untuk menutup defek dan dibentuk sebagai tragus. Luka insisi dijahit lapis demi lapis. Tampon sufratul dipasangkan pada liang telinga kanan dan perban tekan pada retroaurikuler dan preaurikuler. Operasi selesai.

Diagnosis pasca operatif adalah pasca rekontruksi tragus dan kanaloplasti atas indikasi hemifasial mikrosomia dengan tragus asesorius, dan stenosis liang telinga kanan. Terapi pasca operatif adalah injeksi ceftriakson 2x500 mg intra vena (IV), dan drip satu ampul tramadol dalam cairan infus ringer laktat 500 cc dalam waktu 8 jam.

Follow up hari ke-3 pasca operasi, keluar darah dari liang telinga kanan dan luka operasi tidak ada, demam tidak ada. Pemeriksaan fisik, tanda vital dalam batas normal. Luka insisi dan jahitan retroaurikuler dan preaurikuler baik, tidak ada tanda infeksi. Liang telinga kanan terpasang tampon sufratul, tidak ada darah merembes. Pasien boleh pulang dan disarankan kontrol ke poliklinik THT-KL 2 hari lagi (Gambar 6).

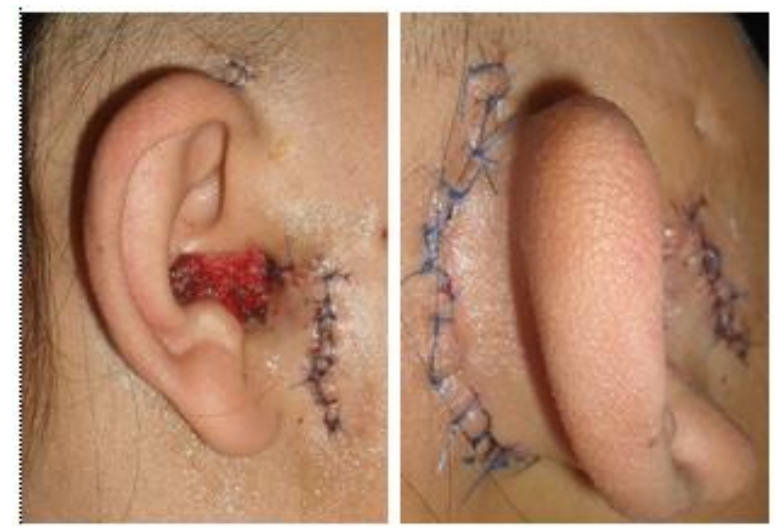

Gambar 6. Foto follow up hari ke-3

Follow up hari ke-5 pasca operasi, keluar darah dari liang telinga kanan dan luka operasi tidak ada, demam tidak ada. Pemeriksaan fisik, tanda vital dalam batas normal. Luka insisi dan jahitan retroaurikuler dan preaurikuler baik, tidak ada tanda infeksi. Liang telinga kanan terpasang tampon sufratul, tidak ada darah merembes. Jahitan insisi diangkat 
sebagian dan disarankan kontrol ke poliklinik THT-KL 2 hari lagi (Gambar 7).
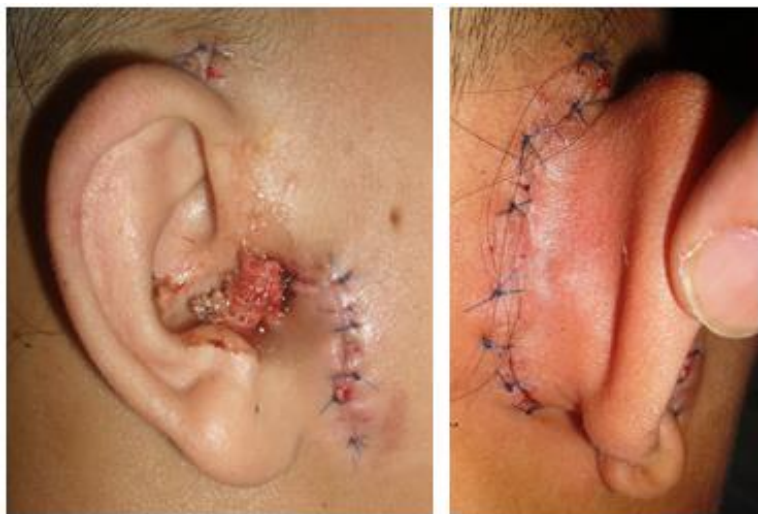

Gambar 7. Foto follow up hari ke-5

Follow up hari ke-7 pasca operasi, keluar darah dari liang telinga kanan dan luka operasi tidak ada, demam tidak ada. Pemeriksaan fisik, tanda vital dalam batas normal. Luka insisi dan jahitan retroaurikuler dan preaurikuler baik, tidak ada tanda infeksi. Liang telinga kanan terpasang tampon sufratul, tidak ada darah merembes. Jahitan insisi diangkat keseluruhan dan disarankan kontrol ke poliklinik THTKL 7 hari lagi (Gambar 8).
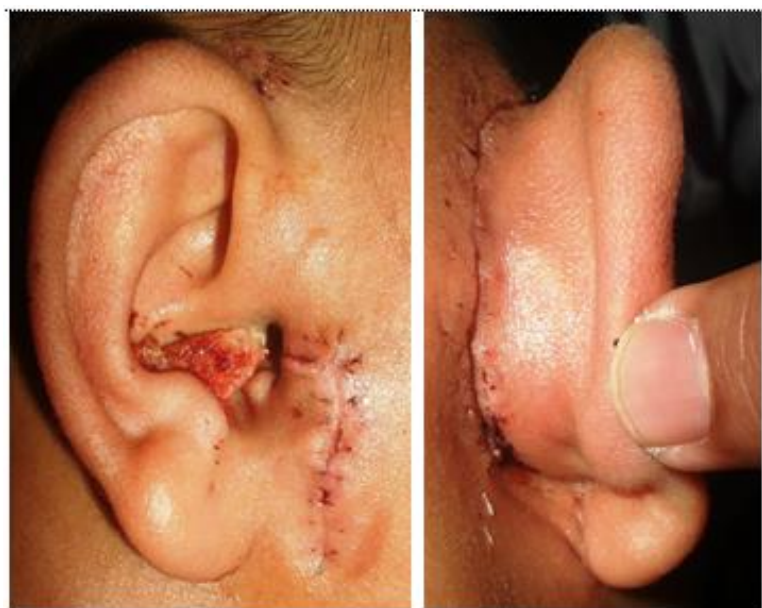

Gambar 8. Foto follow up hari ke-7

Follow up hari ke-14 pasca operasi, keluar darah dari liang telinga kanan dan luka operasi tidak ada, demam tidak ada. Pemeriksaan fisik, tanda vital dalam batas normal. Bekas luka insisi retroaurikuler dan preaurikuler baik, tidak ada tanda infeksi. Liang telinga kanan terpasang tampon sufratul, tidak ada darah merembes. Tampon sufratul diangkat dan dievaluasi liang telinga kanan cukup lapang, pertumbuhan jaringan lunak baik dan membran timpani utuh (Gambar 9).
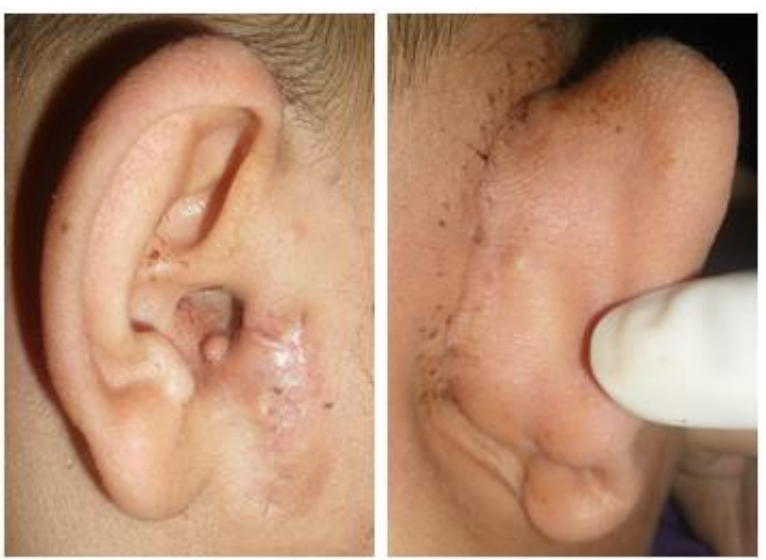

Gambar 9. Foto follow up hari ke-14

Follow up hari ke-28 pasca operasi, bekas luka insisi retroaurikuler dan preaurikuler baik, tidak ada tanda infeksi. Liang telinga kanan cukup lapang, pertumbuhan jaringan lunak baik dan membran timpani utuh serta sekret atau pus tidak ada (Gambar 10). Pemeriksaan Audiometri didapatkan tuli kondukif derajat sedang telinga kanan dengan ambang dengar $41,25 \mathrm{~dB}$.
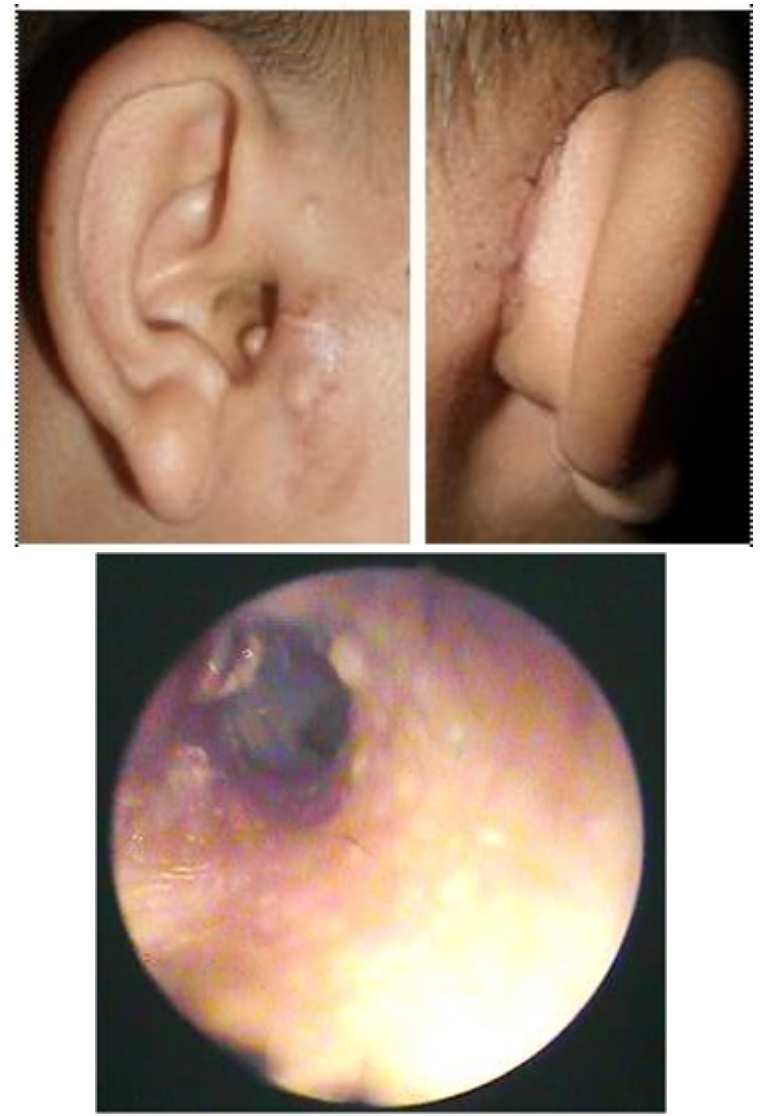

Gambar 10. Foto follow up hari ke-28

\section{DISKUSI}

Sebuah kasus telah dilaporkan pada seorang perempuan usia 13 tahun dengan diagnosis hemifasial mikrosomia dengan tragus asesorius, stenosis liang telinga kanan dan suspek kista dermoid mata kanan. Diagnosis berdasarkan anamnesis, pemeriksaan fisik, dan pencitraan radiologis. 
Pada kasus ini, didapatkan benjolan di daun telinga kanan, liang telinga kanan sempit, wajah sisi kanan mencong, dan benjolan di mata kanan sejak lahir. Riwayat anggota keluarga sakit seperti ini tidak ada. Riwayat ibu pasien trauma atau makan obatobatan tidak ada selama kehamilan. Riwayat ibu pasien menderita diabetes tidak ada.

Teori yang diterima saat ini untuk patogenesis HFM adalah hemoragik akibat disrupsi saat pembentukan arteri stapedius pada perkembangan arkus brankial pertama dan kedua fase embriogenesis. ${ }^{3}$ Pada HFM tidak ada bukti kuat diwariskan secara transmisi genetik. Pada individu anak kembar monozigot sering menunjukan perbedaan manifestasi klinis kelainan ini, meskipun jarang manifestasi klinis yang sama dapat terjadi. Pada kasus yang jarang, terdapat beberapa anomali kromosom yang terkait dengan HFM, kebanyakan delesi segmen kromosom $5 \mathrm{q}$, trisomi 18, dan duplikasi segmen kromosom 7q. ${ }^{1}$ Pewarisan autosomal dominan dan autosomal resesif telah dijadikan hipotesis untuk menjelaskan kejadian yang beragam pada garis keturunan keluarga. ${ }^{12}$

Pemeriksaan fisik didapatkan, pada regio preaurikular kanan terdapat benjolan sewarna kulit berukuran $3 \times 2 \times 2 \mathrm{~cm}$ di tragus, nyeri tekan tidak ada dan terdapat pit. Pemeriksaan liang telinga kanan sempit dan membran timpani sukar dinilai. Pada regio maksilofasial kanan, terdapat hipoplasia pada tulang maksila kanan, zigomatika kanan, dan submandibula kanan, tidak terdapat krepitasi dan nyeri tekan. Pada regio orbita dekstra, terdapat massa sewarna kulit berukuran $2 \times 1 \times 0,5 \mathrm{~cm}$ dari daerah kantus lateral sampai konjungtiva bulbi.

HFM sering terjadi unilateral $(70 \%)$ dan jika bilateral selalu terdapat wajah asimetris. Manifestasi klinis HFM sangat beragam mulai dari wajah asimetris ringan sampai dengan disgenesis berat satu sisi wajah dengan komplikasi orbita, pembentukan tidak sempurna daun telinga sampai dengan agenesis. Dagu dan garis tengah wajah sudah tidak lagi di tengah dan terdeviasi ke arah lesi. Salah satu sudut bibir sering menjadi lebih tinggi dibandingkan yang lain, sehingga garis bibir menjadi tertarik dan miring. Simptom asimetris lainnya adalah hipoplasia tulang maksilaris dan temporalis unilateral, pemendekan arkus zigoma unilateral, dan malformasi telinga luar, tengah dan dalam. Otot maseter, temporal, pterigoid dan otot-otot ekspresi wajah menjadi hipoplasia pada sisi wajah lesi. Tingkat hipoplasia tulang secara langsung berkaitan dengan hipoplasia otot-otot yang melekat pada tulang tersebut. ${ }^{4,13,14}$

Malformasi telinga luar sangat bervariasi. Tuli konduksi karena kelainan telinga tengah atau aplasia atau defisiensi meatus akustikus eksternus telah tercatat pada $30 \%$ sampai $50 \%$ kasus. Sejumlah ear tag dapat terjadi mulai dari tragus sampai dengan sudut bibir. ${ }^{4,11}$

Kanalis akustikus eksternus berasal dari arkus brankial pertama berupa inti solid sel epitel yang meluas ke anulus timpanikus dan kantong faringeal pertama yang terjadi pada minggu ke-6 hingga ke-8 kehamilan. Pada minggu ke-21 terjadi absorbsi sel epitel dari arah medial ke lateral. Jika proses kanalisasi ini berhenti secara prematur, maka kanalis akustikus akan mengalami atresia atau stenosis. $^{12,15}$

Stenosis liang telinga kongenital merupakan salah satu tipe atresia liang telinga derajat ringan. ${ }^{16}$ Liang telinga dapat mengalami stenosis atau atresia dengan derajat yang bervariasi. ${ }^{17}$

Ombredanne membagi atresia liang telinga kongenital menjadi 2 grup, yaitu malformasi mayor dan minor. Malformasi mayor biasanya ditandai dengan agenesis liang telinga luar dan membran timpani, termasuk stenosis liang telinga berat disertai membran timpani yang kecil. Ukuran telinga tengah mengecil dan gangguan perkembangan seperti fusi dan fiksasi maleus dan inkus. Pada kasus yang berat, telinga tengah dapat menjadi hipoplasi berat dengan tulang-tulang pendengaran mengecil atau menghilang. Saraf fasialis terputus dan dislokasi dapat ditemui pada malformasi mayor. Pada malformasi minor banyak melibatkan kelainan telinga tengah. Tuli konduktif dapat disebabkan agenesis, deformitas atau fiksasi salah satu atau lebih tulangtulang pendengaran. Abnormalitas stapes lebih banyak ditemui pada malformasi minor dibandingkan mayor. Kelainan ringan atau bahkan membran timpani dan telinga tengah normal bisa terjadi. Liang telinga luar secara fungsional baik tetapi sedikit mengecil. ${ }^{15,17}$

Pada kasus ini didapatkan stenosis liang telinga minor karena memiliki liang telinga sempit dan tidak ada mikrotia. Tuli konduktif telinga kanan derajat sedang dengan ambang dengar 43,75 dB disebabkan malformasi telinga luar dan tengah.

Sebelum operasi, pasien dilakukan pemeriksaan tomografi komputer pada mastoid dan sinus paranasal dengan hasil disgenesis meatus akustikus eksterna dengan tulang-tulang pendengaran, organ telinga tengah dan dalam baik, serta didapatkan hipoplasia dari tulang zigomatika dan mandibula kanan.

Pada kasus ini ditegakkan diagnosis hemifasial mikrosomia dengan stenosis liang telinga dan tragus asesorius kanan serta diagnosis diferensial sindrom goldenhar, belum dapat disingkirkan karena tidak dilakukan pemeriksaan analisis kromosom.

Berdasarkan klasifikasi modifikasi Pruzansky oleh Kaban dan Mulliken, pasien pada kasus ini dikelompokkan tipe Ila, karena mandibula tipe Ila memiliki kelainan morfologi, tapi masih memiliki fungsi dan posisi TMJ (Temporomandibular Joint) yang baik untuk menunjang pembukaan simetris dari mandibula.

Berdasarkan klasifikasi OMENS, pasien pada kasus ini memiliki $\mathrm{O}_{0}$; karena memiliki ukuran dan posisi orbita masih normal, $\mathrm{M}_{2 a}$; karena ramus 
mandibula memiliki bentuk abnormal dan pendek, serta fosa glenoid masih dalam posisi yang baik untuk menunjang pergerakan TMJ menghasilkan pembukaan mandibula yang simetris, $E_{1}$; hipoplasia atau stenosis liang telinga luar, $\mathrm{N}_{0}$; tidak ada keterlibatan saraf fasial, dan $\mathrm{S}_{2}$; defisiensi moderat jaringan subkutaneus dan otot-otot wajah pada sisi defek.

Anomali telinga tersering adalah atresia tulang liang telinga, aplasia parsial liang telinga, ketiadaan kavum timpani, dan ketiadaan liang telinga luar sering menjadi indikasi yang jelek untuk dilakukan tindakan rekontruksi. Hasil positif perbaikan pendengaran dapat dicapai dengan implan kraniofasial terintegrasi pada tulang atau dikenal dengan Bone Anchored Hearing Aid (BAHA). BAHA dianjurkan karena lebih memberikan manfaat dibandingkan alat bantu dengar konvensional, memberikan iritasi kulit minimal dan lebih dapat diterima secara kosmetik. ${ }^{12,18}$

Eksisi skin tag preaurikula dan sisa kartilago pada usia kurang dari 2 tahun sering bertujuan untuk memuaskan orang tua pasien, karena dapat menghilangkan beberapa simptom dari sindrom ini. Rekontruksi telinga sering dilakukan pada periode usia 6 sampai 15 tahun. Insersi flap bebas mikrovaskuler dapat memperkuat jaringan lunak wajah dan memperbaiki kontur wajah pada sisi yang terkena memberikan perbaikan estetika yang adekuat. ${ }^{6,7,19}$

Terdapat beberapa pertimbangan menentukan waktu relatif manajemen mikrotia terhadap penatalaksanaan deformitas rahang sebagai suatu manajemen keseluruhan. Sebagai contoh, apakah rekontruksi telinga dilakukan pertama atau haruskah tindakan osteotomi distraksi mandibula dan perbaikan bidang oklusi dilakukan terlebih dahulu sehingga posisi rekontruksi telinga akan simetris dengan sisi yang tidak terdapat lesi. Saat ini tidak ada urutan manajeman yang pasti untuk HFM. Manajemen pasien HFM adalah pendekatan multidisiplin yang kompleks dan disesuaikan dengan kebutuhan tiap individual pasien yang sangat spesifik. ${ }^{12,20}$

Pada kasus ini dilakukan tindakan rekontruksi tragus dan kanaloplasti pada telinga kanan dalam anastesi umum. Tujuan penatalaksanaan kasus ini adalah perbaikan fungsi estetika dan fungsi pendengaran. Pasca operasi didapatkan ambang dengar telinga kanan 41,25 dB, tidak ada perbaikan pendengaran yang signifikan karena tidak dilakukan rekontruksi malformasi telinga tengah. Pemeriksaan tomografi komputer mastoid reguler tidak dapat menilai kelainan telinga tengah seperti ukuran dan malformasi tulang-tulang pendengaran. ${ }^{1,2}$

Kesimpulan pada kasus ini, bahwa pasien didiagnosis dengan Hemifasial mikrosomia (HFM), salah satu diagnosis dari kelainan berspektrum luas yang ditandai dengan disgenesis wajah mencakup berbagai derajat hipoplasia/ aplasia dari komponen kerangka tulang dan jaringan lunak pembentuk wajah. Kasus ini telah dilakukan rekontruksi tragus dan kanaloplasti untuk memperbaiki estetika dan fungsi pendengaran pada telinga kanan, karena HFM memiliki manifestasi klinis beragam, termasuk kelainan pada telinga luar serta dipertimbangkan mendapatkan penatalaksanaan komprehensif yang melibatkan rekontruksi medik luas.

\section{DAFTAR PUSTAKA}

1. Havlik RJ, Schleich AR. Chapter 47: Hemifasial mikrosomia. In:Guyuron B, Erksson E, Persing JA editors. Plastic Surgery. 1st edition. China: Saunders; 2009.605-18.

2. Grabb W. The first and second branchial arch syndrome. Plast Reconstr Surg. 1965; 36:485508.

3. Blaszczak MM, Olszewska K. Hemifasial mikrosomia - Review of the Literature. Dent. Med. Probl. 2011;48(1):80-85.

4. Dhillon M, Mohan RP, Suma GN, Raju SM, Tomar D. Hemifasial mikrosomia: a clinicoradiological report of three cases. Journal of Oral Science 2019; 52(2):319-324.

5. Gorlin R. Oculoauriculovertebral dysplasia. J Pediatr 1963; 63:991.

6. Monahan R., Seder K., Patel P., Alder M., Grud S., O'Gara M. Hemifacial microsomia: etiology, diagnosis and treatment. J. Am. Dent. Assoc. 2001; 132:1402-1408.

7. McCarthy JG. Chapter 26: Craniofacial Microsomia. In:Thorne $\mathrm{CH}$ editor. Grabb and Smith's Plastic Surgery. 6th edition. Darmouth: Lippincott Williams and Wilkins; 2007.248-55.

8. Silvestri A, Natali G, Fadda MT. Dental agenesis in hemifasial mikrosomia. Pediatric Dentistry 1996; 8(1): 48-51.

9. Robinson LK, Hoyme HE, Edward DK, Jones KL. Vascular pathogenesis of unilateral craniofacial defects. J Pediatr. 1987;2:236-39.

10. Rollnick B, et al. Oculoauriculo vertebral dysplasia and variants: phenotypic characteristics of 294 patients. Am J Med Genet 1987;26:361375.

11. Vento AR, LaBrie RA, Mulliken JB. The OMENS Classification of Hemifasial mikrosomia. Cleft Palate-Craniofacial Journal 1991;28(1):68-76.

12. Wang RR, Andres CJ. Hemifasial mikrosomia and treatment options for auricular replacement: A review of the literature. J Prosthet Dent 1999;82:197-204.

13. Marsh JL, Baca D, Vannier MW. Facial Musculoskletal Asymmetry in Hemifasial mikrosomia. Cleft Palate Journal 1989;26(4):292301.

14. Moulin-Romsée C, Verdonck A, Schoenaers J, Carels $\mathrm{C}$. Treatment of hemifacial microsomia in a growing child: the importance of co-operation between the orthodontist and the maxillofacial surgeon. J Orthod 2004;31:190-200.

15. Lambert PR. Congenital Aural Atresia. In: Bailey BJ, Johnson JT, Newlands SD, editors. Head\&Neck Surgery-Otolaryngology. 4th ed. Lippincott Williams \& Wilkins: Texas; 2006. p. 2029-40

16. Yamane H, Takayama M, Sunami K, Tochino R, Morinaka M. Disregard of Cholesteatoma in 
Congenital Aural Stenosis. Acta Otolaryngol. 2007;127(2):221-4

17. Kesser BW, Matthew NG, Horlbeck DM. Aural Atresia. [Update Mar 25, 2010; cited Sept 20, 2014].

Available from:http://www.emedicine.medscape.com/article /878218-overview

18. Martinelli $P$, Maruotti GM, Agangi A, Mazzarelli LL, Bifulco G, Paladini D. Prenatal diagnosis of hemifasial mikrosomia and ipsilateral cerebellar hypoplasia in a fetus with oculoauriculovertebral spectrum. Ultrasound Obstet Gynecol 2004; 24: 199-201.

19. Kaplan RG. Induced Condylar Growth in a Patient with Hemifasial mikrosomia. Angle Orthodontist 1990;59(2):85-90.

20. Losken HW, Preston CB, Evans WG. Hemifasial mikrosomia. SA Med. Journal 1983;64:500-2. 